\title{
HISTORIA ROZWOJU KATOLICKIEJ SIECI PARAFIALNEJ W DIECEZJI TYRASPOLSKIEJ W XIX WIEKU NA PODSTAWIE MATERIALÓW PAŃSTWOWEGO ARCHIWUM OBWODU ODESKIEGO
}

Ludność północnego wybrzeża Morza Czarnego, która od końca XVIII wieku weszła w skład imperium rosyjskiego, wyróżniała się niejednolitym etnicznym składem i przynależnością do różnych wyznań religijnych. Dominującą pozycję zajmowała Cerkiew prawosławna, posiadająca największą liczbę wyznawców. Ponadto sporą część mieszkańców stanowili katolicy, którzy przybyli do tego regionu z państw europejskich, czyli: Polacy, Włosi, Niemcy, Hiszpanie i Francuzi. Osiedlili się oni głównie w Odessie, Chersoniu, Mikołajewie i innych miejscowościach Noworosyjskiego Kraju. Ludność katolicką objęła swym zasięgiem nowo powstała metropolia mohylewska (1783), na czele której w 1798 roku stanął metropolita Stanisław Bohusz-Siestrzeńcewicz. Celem niniejszego artykułu jest prześledzenie, na podstawie dokumentów zachowanych w Państwowym Archiwum Obwodu Odeskiego, dziejów katolickich parafii w Odessie i przedstawienie pozycji wyższego duchowieństwa prawosławnego odnośnie do ich rozwoju w XIX wieku.

Kościół katolicki na ziemiach współczesnej południowej Ukrainy przeszedł kilka etapów rozwoju. Pierwszy z nich trwał od końca XVIII wieku do lat 20. XIX wieku. Można go scharakteryzować jako najbardziej pomyślny dla rozprzestrzenienia się katolicyzmu na tych ziemiach. W tym okresie bowiem zarząd Noworosyjskiego Kraju przychylnie ustosunkował się do nieprawosławnych emigrantów. Między innymi generał-gubernator Armand Emmanuel de Richelieu zaprosił księży jezuitów, działających w Rosji za zgodą Katarzyny II, by objęli opieką duszpasterską nowo przybyłych. W 1811 roku powołano wizytatora kościołów rzymsko-katolickich w Noworosyjskim Kraju, który jednocześnie był proboszczem odeskiej parafii. Pierwszym wizytatorem mianowano jezuitę, o. Nikola, który nadzorował działalność wszystkich katolickich parafii znajdujących się w: Odessie, Chersoniu, Mikołajewie, Sewerynówce i w szeregu niemieckich kolonii,

* Natalia Mykołajiwna Dianowa - dr historii, docent w Katedrze Historii Ukrainy na Wydziale Historii Państwowego Uniwersytetu w Odessie; e-mail: dzess2009@rambler.ru 
jak: Landau, Manheim, Selz, Rastad i innych ${ }^{1}$. Ale w 1820 roku wypędzono jezuitów z Rosji, powołując się na naruszenie zakazu pracy wśród ludności prawosławnej. Na miejsce o. Nikola przyszedł Ignacy Lindl, Bawarczyk, dwa lata później również wydalony z Imperium, tym razem za propagowanie protestantyzmu ${ }^{2}$.

W odeskim archiwum obwodowym ${ }^{3}$ zachowały się źródła, na podstawie których można fragmentarycznie prześledzić rozwój katolicyzmu w południowym regionie, a przede wszystkim w Odessie. Dokumenty znajdują się w zespołach zarządu noworosyjskiego i besarabskiego generał-gubernatora (z. 1), głównego statystycznego komitetu Noworosyjskiego kraju (z. 3), Odeskiego Komitetu Budowlanego (z. 59) oraz zarządu parafii św. Piotra w Odessie (z. 628) ${ }^{4}$. Niestety do naszych dni dotarwały tylko szczątkowe materiały dotyczące parafii katolickich w tym regionie, gdyż wiele zespołów zostało bezpowrotnie utraconych w okresie II wojny światowej.

Część archiwalnej dokumentacji dotyczy dziejów pierwszej katolickiej świątyni w Odessie - pod wezwaniem Wniebowzięcia NMP, zbudowanej w roku 1795 ze składek parafian. $Z$ czasem stała się ona zbyt ciasna dla znacząco wzrastającej na początku XIX wieku liczby parafian. W związku z tym w 1811 roku duchowni katoliccy zwrócili się do Odeskiego Komitetu Budowlanego z prośbą o wydanie oficjalnego pozwolenia na władanie ziemią w kwartale wokół świątyni. Uzyskano pomyślną odpowiedź i parafia dostała na własność teren pomiędzy ulicami: Jekateryńską, Policejską (dzisiaj Bunina), Richeliewską i Pocztową (dzisiaj Żukowskiego), ogółem 2925 sążni kwadratowych ${ }^{5}$. Rok później włoski architekt Francesco Morandi rozpoczął prace budowlane, które trwały właściwie do 1853 roku. Chociaż nowy kościół ukończono już w latach 20. XIX wieku, to już wówczas nie mógł on pomieścić wszystkich wiernych, i jeszcze dwukrotnie był rozbudowywany.

Po powstaniu listopadowym (1830-1831) rozpoczęły się represje rządu rosyjskiego wobec Kościoła katolickiego, który oskarżano o wsparcie powstańców. Ponadto, ujawniła się wyraźna tendencja podporządkowania go Cerkwi prawosławnej. Wtrącanie się władz świeckich i prześladowania Kościoła spowodowały negatywną reakcję papieża i państw europejskich. Incydent został ułagodzony poprzez rozpoczęcie rozmów między Stolicą Apostolską i Petersburgiem, które zakończyły się podpisaniem w 1847 roku konkordatu. Jeden z artykułów konkordatu dotyczył utworzenia nowej - chersońskiej - diecezji dla katolików południowej Rosji.

${ }^{1}$ Ł. Gędłek, T. Krzyżowski, M. Żurek, Zarys historii diecezji odesko-symferopolskiej, Odessa -Kraków 2011, s. 23-24.

${ }^{2}$ Н. М. Діанова, Формування етно-конфесійної структури населення міст Південної України (кінець XVIII - перша половина XIX ст.), Одеса 2010, s. 114.

${ }^{3}$ Państwowe Archiwum Obwodu Odeskiego - Державний Архів Одеської Області (dalej: ДАОО).

4 Ф. 1 - «Управление Новороссийского и Бессарабского генерал-губернатора»; Ф. 3 «Главный статистический комитет Новороссийского края, Ф. 59 - «Одесский строительный комитет», Ф. 628 - «Правление Римско-католической церкви Св. Петра в Одессе».

5 ДАОО, ф. 628, оп. 1, д. 1, к. 3. 
Decyzja o powołaniu nowej diecezji katolickiej oburzyła duchowieństwo prawosławne. Chersoński i taurydzki arcybiskup Innocenty (Borysow) był głęboko przekonany, że utworzenie tej jednostki administracyjnej Kościoła spowodowane było ustępstwem wobec Rzymu, które przyniesie w przyszłości ogromne szkody dla państwa. Przekształcenie Chersonia w centrum katolicyzmu na południu Rosji doprowadziłoby bowiem do aktywizacji działalności misjonarskiej duchowieństwa katolickiego i zwiększyłoby liczbę katolików wśród ludności regionu.

Działania te mogły w sposób negatywny odbić się na sytuacji prawosławnej cerkwi, która w warunkach natarcia protestantyzmu musiała wielorako bronić swej dominującej pozycji w społeczeństwie. Jednym ze sposobów postępowania prawosławnego duchowieństwa była praca kaznodziejska wśród wyznawców innych religii, w tym także katolików, w celu pozyskania ich dla prawosławia. Jednak zabiegi te przynosiły skromne rezultaty. Tak w 1844 roku w chersońskiej eparchii z katolicyzmu na prawosławie przeszły 64 osoby, a w jekaterynosławskiej $-65^{6}$. Pomimo zaangażowania duchowieństwa prawosławnego $\mathrm{w}$ następnych latach, w 1913 w chersońskiej eparchii 40 katolików zmieniło wyznanie na prawosławne, w jekaterynosławskiej 11, w taurydzkiej - 40. Równocześnie z prawosławia na katolicyzm przeszło odpowiednio 14, 4 i 17 osób ${ }^{7}$.

Arcybiskup Innocenty (Borysow) dążył do rozprzestrzenienia nauk Cerkwi prawosławnej w katolickim środowisku. W latach 1845-1846 niektóre jego kazania, m.in. Liturgia św. Jana Zlotoustego i Pierwszy tydzień Wielkiego Postu zostały przetłumaczone na język francuski i opublikowane we Francji, a w następnym roku greckie tłumaczenie tych kazań wyszło w Atenach. Dzięki tym publikacjom europejscy czytelnicy mieli okazję zapoznać się bliżej z teologią prawosławną. Po przeczytaniu tekstów abpa Innocentego Francuzi pisali, że jego kazania dały im możliwość po raz pierwszy poznać prawosławie. Doceniali także kaznodziejski talent arcybiskupa oraz jego głęboką znajomość Pisma Świętego. Należy przyznać, że jego kazania były pożyteczne i pouczające dla wszystkich chrześcijan bez względu na ich przynależność etniczną czy wyznaniową ${ }^{8}$.

Autorytet Innocentego (Borysowa) oraz jego wpływ na społeczeństwo i aktywna pozycja w chersońskiej diecezji zmusiła rząd do ponownych rozmów ze Stolicą Apostolską. Wynikiem tychże było przeniesienie stolicy nowego biskupstwa do Tyraspola i przemianowanie diecezji na tyraspolską. Diecezja te weszła w skład metropolii mohylewskiej. Jednak rezydencja biskupów początkowo znajdowała się w Odessie, a nowo zbudowana, murowana świątynia Wniebowzięcia NMP stała się katedralną. Proboszczem prokatedry został ks. Jerzy Bezutowicz, którego prace wspierało czterech kapłanów prowadzących duszpasterstwo i kazania dla: Polaków, Niemców, Włochów i Francuzów. Katolicka społeczność Odessy pod względem liczebności dominowała na południu Ukrainy, i miąła tendencję wzrostową. W 1857 roku w Odessie mieszkało 3063 osób wyznania

${ }^{6}$ Извлечение из отчета обер-прокурора Святейшего Синода за 1844 год, Санкт Петербург 1845 , Приложения, s. 44-45.

${ }^{7}$ Всеподданейший отчет обер-прокурора Святейшего Синода по ведомству православного исповедания за 1813 г., Санкт Петербург 1813, Приложение, s. 34-40.

${ }^{8}$ ДАОО, ф. 167, оп. 1, д. 3, к. 17; д. 4, k. 7-8. 
katolickiego, w Chersoniu - 305, Mikołajewie - 1 500, Wozniesieńsku - 203 i w Ananiewie - 309. Już w 1860 roku, według danych Głównego Statystycznego Komitetu Noworosyjskiego Kraju w Odessie było już 4224 katolików, co stanowiło około 4\% ogólnej liczby mieszkańców ${ }^{10}$. W 1873 roku, zgodnie z danymi Odeskiego Statystycznego Komitetu w mieście pracowało 14 katolickich kapłanów wśród 8616 wiernych (4 955 mężczyzn i 3661 kobiet) ${ }^{11}$.

W związku ze wzrostem liczebności katolickiej wspólnoty parafia zakupiła dom lekarza Pieszki, który przylegał do jej zabudowań (225 sążni kw.). Zarząd katolickiej parafii zwrócił się do odeskiego zarządu miejskiego z prośbą o wystawienie aktu własności ziemi ze wszystkimi zabudowaniami, podobnie jak i w 1811 roku. Ta prośba również została pomyślnie rozpatrzona przez dumę miejską 10 maja 1889 roku $^{12}$. Pod koniec XIX wieku jednak odeska parafia nie mogła już objąć opieką pasterską całej ludności katolickiej miasta. Dlatego też w 1892 roku duchowieństwo zwróciło się z prośbą do władz miasta o wydzielenie miejsca przy ul. Bałkowskiej na budowę nowego kościoła, plebanii, szkoły parafialnej oraz domu opieki dla biednych i starszych osób. Znajdowała się tam już kaplica. Duma miejska i jej przewodniczący G. Marazli 16 listopada 1892 roku podpisali rozporządzenie o nieodpłatnym przekazaniu placu (1659 sążni kw.). Proboszczem nowej, budowanej świątyni pod wezwaniem św. Klemensa został ks. Józef Szejner ${ }^{13}$. W następnym roku (1893) przy ulicy Hawannej z inicjatywy francuskich emigrantów zbudowano kościół św. Piotra, nazywany odtąd w Odessie francuskim.

Powstanie trzech parafii w ciągu XIX wieku w dynamicznie rozrastającym się mieście portowym nie zaspokajało potrzeb wiernych już na początku wieku następnego. W archiwum zachował się dokument o próbie utworzenia czwartej placówki ${ }^{14}$. W 1918 roku odeska parafia Wniebowzięcia NMP zakupiła majątek Wincentego Szeliota w rejonie Mołdawanki, płacąc za 408 sążni kw. ziemi sześć tysięcy rubli ${ }^{15}$.

Tyrapolski biskup katolicki zapraszał do opieki nad Niemcami-katolikami duszpasterzy z innych państw niemieckich lub Austrii. Tłumaczył on swe prośby po pierwsze: brakiem kleryków pochodzenia niemieckiego w seminarium tyraspolskim, a po drugie: trudnym charakterem proboszcza odeskiej parafii. Proces ten jednak był ściśle kontrolowany przez przedstawicieli władzy świeckiej. Jeden z przykładów znajduje się w miejscowym archiwum. 7 kwietnia 1859 roku syndycy odeskiej parafii zwrócili się z prośbą do noworosyjskiego i besarabskiego

\footnotetext{
${ }^{9}$ Санкт-Петербургский филиал архива Российской Академии Наук, ф. 30, оп. 1, д. 64, k. 455-459.

${ }^{10}$ ДАОО, ф. 3, оп. 1, д. 60, k. 46.

${ }^{11}$ ДАОО, ф. 274, оп. 1, д. 30, k. 20, 21.

12 ДАОО, ф. 628, оп. 1, д. 1, k. 6-9.

${ }^{13}$ ДАОО, ф. 3, оп. 1, д. 54, k. 76.

${ }^{14}$ ДАОО, ф. 628, оп. 1, д. 1, k. 11-12.

${ }^{15}$ Dalsze dzieje parafii odeskich zob. T. Krzyżowski, Zarys dziejów Kościoła katolickiego w Odessie (1917-1991), w: Regiones euxinum spectantes. Stosunki kulturowe, etniczne i religijne na przestrzeni dziejów, red. Ł. Gędłek, T. Krzyżowski, M. Michalski, Kraków 2012.
} 
generał-gubernatora hr. A. G. Stroganowa, w którym prosili o przysłanie z zagranicy kapłana niemieckiego pochodzenia dla duszpasterstwa wśród niemieckich osadników, w związku z wyjazdem niemieckiego ks. Leopolda Borii. Po uzyskaniu pozytywnej odpowiedzi, do Odessy przybył austriacki poddany ks. Piotr Mali. Jednak, jak informował dziekan chersońskiej guberni, nie mógł on przystąpić do wykonania swych zadań bez specjalnego pozwolenia rządu rosyjskiego. Rozwiązać problem można było wyłącznie przy osobistym udziale Stroganowa. Gubernator skierował pismo do MSW i 16 listopada 1869 roku otrzymał odpowiedź od ministra spraw wewnętrznych Łanskoja. Jednak minister oznajmił, że ks. P. Mali nie może uzyskać pozwolenia na wykonanie swych obowiązków gdyż nie pozwala mu to rosyjskie prawodawstwo. Po pierwsze, zaproszenie dla duchownego z zagranicy wystosować mogli tylko parafianie-cudzoziemcy poprzez rosyjskie misje dyplomatyczne, pod warunkiem uzyskania wcześniejszej zgody na to MSW. Po drugie, na podstawie prawa paszportowego obowiązującego w Rosji, misje rosyjskie i konsulaty były zobowiązane uzyskać pisemne potwierdzenie przy wydaniu paszportów dla księży katolickich wjeżdżających do Rosji, że nie należą oni do zakonu jezuitów oraz tajnych towarzystw. Dopiero po otrzymaniu tych informacji stawiali odpowiedni zapis w paszporcie. Ponieważ procedura nie została spełniona przy wjeździe ks. P. Mali do Rosji, ministerstwo nie posiadało żadnego potwierdzenia jego lojalności i nie mogło pozwolić na pracę duszpasterską w Odessie ${ }^{16}$.

Dla badań nad dziejami kościelnymi ważnym źródłem są księgi metrykalne, które odzwierciedlają życie wiernych. W archiwum (z. 628) są przechowywane księgi metrykalne odeskiej parafii Wniebowstąpienia NMP, katolickiej parafii w mieście Bałta (obwód odeski), kościoła w Krasnym, Besarabia (obecnie rejon tarutyński, obwód odeski), katolickiej parafii we wsi Manheim (obecnie wieś Mychajliwka, rejon rozdilniański, obwód odeski) i Sewerynówce, również leżącej w wieku XIX w powiecie odeskim, chersońskiej guberni (obecnie obwód odeski). Posiadają one różny stopień informacyjności i obejmują różny okres czasowy. Dla przykładu: księga metrykalna kościoła pod wezwaniem Wniebowzięcia NMP o ślubach prowadzona była w latach 1867-1878. Zapisywano tu corocznie liczbę ślubów oraz kraj, z którego pochodzili małżonkowie. Największa liczba ślubów była w 1873 roku (71) a najmniejsza - w 1878 r. (24) ${ }^{17}$.

Księga zapisów o zgonach parafii sewerynowskiej obejmuje lata 1844-1858. Miasteczko Sewerynówka było własnością radcy tajnego hr. Leona Potockiego. Znajdowało się ono 38 wiorst od Odessy. Do parafii należało 10 wsi i dwa futory. W samym miasteczku zbudowano dwie świątynie chrześcijańskie - prawosławną i katolicką oraz synagogę ${ }^{18}$. Proboszczem w 1844 roku był ks. Symon Szczeniewski. Zapisy w księdze świadczą o tym, że śmiertelność w Sewerynówce i jej okolicach nie była wysoka. Odnotowywano głównie zgony osób starszych i noworodków. Najniższa śmiertelność była w latach 1852-1853 i 1858 (po dwie osoby), a najwyższa w 1856 (11 osób).

\footnotetext{
16 ДАОО, ф. 1, оп. 197, д. 118, k. 1-4, 6, 10-11.

17 ДАОО, ф. 628, оп. 1, д. 4, k. 1-145.

${ }^{18}$ ДАОО, ф. 270, оп. 1, д. 21, k. 1.
} 
W dokumencie tym mamy również informacje o pochodzeniu społecznym i przynależności państwowej ${ }^{19}$.

W księdze metrykalnej parafii we wsi Manheim rejestrowano chrzty w niemieckich koloniach: ${ }^{20}$ Manheim, Elzas, Baden, Zelc i innych od 1819 do 1835 roku. Najmniejsza liczba urodzeń w koloniach była w latach 1822 i 1823 (po 7 dzieci) a największa - w 1831 r. (87 osób) ${ }^{21}$. Zachowała się księga metrykalna $\mathrm{z}$ tego kościoła, gdzie wpisywano śluby w wyżej wspomnianych koloniach niemieckich. Obejmuje ona lata 1814 do 1847 i zawiera 189 wpisów ${ }^{22}$.

W związku z brakiem wszystkich ksiąg metrykalnych i wystarczającej liczby dokumentacji, informacje o katolickich parafiach nie są pełne. Ponadto, nie zachowały się księgi metrykalne odeskich kościołów pw. św. Klemensa i św. Piotra, a także kaplicy pw. św. Antoniego Padewskiego ${ }^{23}$. Jednak te nieliczne zachowane archiwalne materiały wraz z opublikowanymi źródłami i historycznymi publikacjami dają możliwość odtworzenia historii rozwoju parafii katolickich w Odessie w wieku XIX oraz jej relacji z Cerkwią prawosławną.

słowa kluczowe: parafie, diecezja tyraspolska, XIX wiek, Kościół rzymskokatolicki, obwód odeski

Tt. Irena Wodzianowska

\begin{abstract}
THE HISTORY OF THE DEVELOPMENT OF THE CATHOLIC PARISH NETWORK IN THE DIOCESE OF TIRASPOL IN THE 19TH CENTURY BASED ON THE MATERIALS FROM THE STATE ARCHIVE OF THE ODESSA DISTRICT
\end{abstract}

\title{
Summary
}

The article presents the documents found in the National Archive of the Odessa District. The documents concern a network of Catholic parishes and religious life. Several fonds contain archival materials referring to churches built in Odessa and clergy encouraged to work among the German settlers, and registry books of some parishes. The last ones are a valuable source for determining social origin and the countries from which the settlers arrived. Some of the materials also concern relations with the Orthodox Church, which has a dominant position in the Russian Empire. Archival materials fill in the gaps in already known sources and publications on Catholic parishes on the south coast of the Black Sea.

Keywords: parishes, the Diocese of Tiraspol, the 19th century, the Roman Catholic Church, the Odessa District

Translated by Aneta Kiper

19 ДАОО, ф. 628, оп. 1, д. 5, k. 1-19.

${ }^{20} \mathrm{O}$ niemieckich koloniach zob. szerzej: J. Schnurr, Die Kirchen und das reliogiöse leben der Russlanddeutschen. Katholischer teil, Stuttgart 1980.

${ }^{21}$ ДАОО, ф. 628, оп. 1, д. 3, k. 1-74.

22 ДАОО, ф. 628, оп. 1, д. 2, k. 1-4.

23 Державний архів Одеської області. Зведений каталог метричних книг, випуск I: 1797 1939, упоряд. Л. Г. Білоусова, С. Є. Березін, С. М. Герасимова та інші, Одеса 2011, s. 180. 